\title{
ZMENY MIERY PSYCHOPATOLÓGIE U PACIENTOV ZÁVISLÝCH OD ALKOHOLU VO VZŤAHU K DĹŽKE LIEČBY A SÚVISLOSTI S UŽíVANÍM ALKOHOLU
}

\author{
Michal Kotian 1 - Vladimír Stanislav 3 - Miloš Šlepecký 1,2 - Michaela \\ Chupáčová ${ }^{1}$ - Antónia Kotianová ${ }^{1,2}$ - Marta Zat'ková ${ }^{2}$ - Mária Martinove ${ }^{3}$ - \\ Marta Popelková ${ }^{2}$ - Jan Praško ${ }^{4}$
}

\author{
1 Psychagogia, Ambulancia klinickej psychológie Liptovský Mikuláš \\ 2 Katedra psychologických vied FSVaZ UKF Nitra \\ 3 Odborný liečebný ústav psychiatrický Predná Hora \\ 4 Klinika psychiatrie, Lékařská fakulta, UP Olomouc, ČR \\ Korešpondenčný autor: Mgr. Michal Kotian, michal.kotian@gmail.com
}

\begin{abstract}
Abstrakt: Abstrakt Ciel'om tejto práce bolo preskúmat' vzt'ahy závažnosti vzorca užívania alkoholu a miery psychopatológie u pacientov závislých od alkoholu a porovnat' zmeny psychopatológie počas liečby vzhl'adom $\mathrm{k}$ dížke liečby $\mathrm{v}$ troch rôznych zariadeniach na liečbu závislosti v Slovenskej republike, Českej republike a Pol'sku. Výskumný súbor tvorilo 380 pacientov závislých na alkohole (282 mužov a 98 žien) s priemerným vekom 44,58 roka $(+10,48)$. Z toho 212 pacientov bolo liečených v liečebnom ústave OLÚP Predná Hora, 117 v zariadení Wotuw Krakow a 51 pacientov bolo z psychiatrickej liečebne Jemnice. 60\% pacientov malo minimálne jednu d’alšiu psychiatrickú diagnózu. Účastníkom výskumu boli administrovaný skríningový dotazník nadmerného užívania alkoholu AUDIT (Alcohol Use Disorder Identification) a dotazník psychopatológie SCL-90 (The Symptom checklist 90) postihujúci 9 oblastí. Preukázali sme signifikantný vzt'ah medzi všetkými škálami SCL-90 a výsledným skóre dotazníka AUDIT. Zistili sme signifikantné rozdiely medzi výsledným skóre SCL-90 na začiatku liečby $\mathrm{v}$ porovnaní s koncom liečby, kde k najvýraznejšiemu poklesu psychopatológie dochádza v prvých 6 týždňoch liečby.
\end{abstract}

Klúčové slová: závislost' od alkoholu, liečba, psychopatológia

ÚVOD

Syndróm závislosti od alkoholu je skupina fyziologických, behaviorálnych a kognitívnych fenoménov, pre ktorý je typické, že užívanie alkoholu má u jednotlivca ovel’a väčšiu dôležitost' než iné veci v živote. Centrálnou popisnou charakteristikou syndrómu závislosti je silná túžba užívat' alkohol. Definitívna diagnóza závislosti by sa obvykle mala stanovit’ vtedy, ak v priebehu roka došlo k trom alebo viacerým z nasledujúcich javov:

- silná túžba alebo pocit užit’ látku,

- t'ažkosti v sebaovládaní pri užití alkoholu,

- pretrvávajúce užívanie alkoholu napriek škodlivým dôsledkom v živote jednotlivca,

- uprednostňovanie užívania alkoholu pred inými aktivitami a povinnost'ami,

- telesný odvykací stav - alkohol je užívaný s úmyslom zmenšit' príznaky vyvolané predchádzajúcim užívaním alkoholu, prípadne dochádza k odvykaciemu stavu,

- tolerancia $\mathrm{k}$ účinku alkoholu - vyžadovanie vyšších dávok alkoholu, aby sa dosiahol účinok pôvodne vyvolaný nižšími dávkami (WHO, 1993).

Závislost' od návykových látok je celosvetový problém, ktorý sa spája s vysokou mierou komorbidity. Vo vel'kých epidemiologických štúdiách sa vyskytovala komorbidita závislosti od 
alkoholu s inou psychiatrickou diagnózou v približne polovici prípadov (e.g. Regier et al., 1990; Grant et al., 2004), pričom závažnejší vzorec užívania alkoholu sa spája s vyššou mierou psychopatológie (Ewusi - Mensah et al., 1986) a pochopitel'ne s vyššími personálnymi a finančnými nákladmi na liečbu (Ipser et al., 2015). Pre stanovenie liečby môže byt' zásadné, či je primárna diagnóza závislosti, alebo komorbídna porucha, napr. depresia (Dongier, 2005).

Ciel'om tejto práce bolo preskúmat' vzt’ahy závažnosti vzorca užívania alkoholu a miery psychopatológie u pacientov závislých od alkoholu a porovnat' zmeny psychopatológie počas liečby vzhl’adom k dížke liečby v troch rôznych zariadeniach na liečbu závislosti v Slovenskej republike, Českej republike a Pol'sku. Stanovili sme i hypotézu a výskumnú otázku:

Hypotéza č. 1 (H1): Predpokladáme kladný korelačný vzt'ah medzi závažnost'ou užívania alkoholu (vyjadrenou celkovým skóre dotazníka AUDIT) a mierou psychopatológie.

Výskumná otázka č. 1 (V01): Aké sú zmeny miery psychopatológie u pacientov vzhl’adom k dížke liečby?

\section{Charakteristika liečebných zariadení}

V zariadení Wotuw Krakov je možné absolvovat' ambulantnú a ústavnú formu liečby. K dispozícii je 60 lôžok, kde pacient po detoxikácii absolvuje 7 týždňovú liečbu režimového charakteru. Liečebné zariadenie OLÚP n.o. Predná Hora poskytuje 12 týždňovú ústavnú liečbu režimového charakteru, kde má k dispozícii 200 lôžok. Psychiatrická liečebňa v Jemniciach disponuje približne 60 lôžkami pre psychiatrických pacientov a pacientov, ktorí sa chcú liečit' zo závislosti. Pacienti môžu absolvovat' 6 aj 12 týždňovú liečbu.

\section{Metódy zberu údajov}

Alcohol Use Disorders Identification Test (AUDIT) (Babor et al., 1992): je desat'položkový dotazník vyvinutý Svetovou zdravotníckou Organizáciou (WHO), ktorý slúži ako jednoduchá metóda skríningu pre nadmerné užívanie alkoholu.

The Symptom checklist 90 (Degoratis, 1992) - je psychologický dotazník, ktorý obsahuje 90 položiek rozdelených do 9 škál psychopatológie (indexy somatizácie, obsesií a kompulzií, interpersonálnej senzitivity, depresie, anxiety, hostility, fobickej anxiety, paranoidnej ideácie a psychoticizmu) a index celkovej závažnosti psychopatológie. Úlohou respondenta je na pät'bodovej Likertovej škále (0 - vôbec nie až 4 - vel'mi silno) uviest', do akej miery sa u neho daný symptóm vyskytuje. SCL- 90 umožňuje overit' prítomnost' existujúcich patopsychologických a psychopatologických symptómov a posúdit' možnost' problémov v správaní a prežívaní, resp. existenciu psychickej alebo osobnostnej problematiky alebo poruchy.

\section{Spôsob a metódy spracovania dát}

Pre spracovanie výskumných dát sme použili štatistické testy pomocou programu Statistical Packages for the Social Sciences (SPSS 16.0) pre Windows, prostredníctvom ktorého sme vykonali deskriptívnu a korelačnú analýzu výskumných dát. 


\section{VÝSLEDKY}

\section{Výskumný súbor}

Výskum absolvovalo 380 účastníkov (282 mužov a 98 žien ) s diagnózou závislosti od alkoholu, priemerného veku 44,58 rokov ( $S D=10,48)(44,04$ rokov u mužov; 46,18 rokov u žien). 212 pacientov podstupovalo liečbu v odbornom liečebnom ústave psychiatrickom Predná Hora, 117 pacientov v zariadení Wotuw Krakow v Pol'sku a 51 pacientov psychiatrickej liečebne Pateb Jemnice v Českej republike.

\section{Sociálne zázemie pacientov so závislost'ou od alkoholu}

46,5 \% pacientov bolo v čase nástupu na liečbu nezamestnaných, 36,7 \% bolo zamestnaných, 6,9 \% pacientov bolo na invalidnom, resp. starobnom (9 \%) dôchodku. Medzi nezamestnanými, zamestnanými a dôchodcami sme nezaznamenali signifikantné rozdiely v závažnosti užívania alkoholu (K-W=3,64; sig.=0,30) ani v závažnosti psychopatológie (K-W=5,38; sig.=0,15).

10,7 \% pacientov bolo vysokoškolsky vzdelaných, stredoškolské vzdelanie s maturitou v Českej republike a na Slovensku, resp. stredoškolské vzdelanie v Pol'sku dosiahlo spolu 37,9\% pacientov, stredoškolské bez maturity v Českej republike a na Slovensku, resp. „zawodowe“ (ktoré je ekvivalentom odborného stredoškolského vzdelania bez maturity v SR a ČR) v Pol’sku dosiahlo spolu 42,2 \% pacientov. Nižšie ako spomenuté vzdelanie malo 9,2 \% pacientov.

37,4 \%všetkých pacientov bola v dobe liečenia v manželstve, 30,1 \% pacientov bolo slobodných, 28,7 \% bolo rozvedených a 3,8 \% ovdovených. Pri porovnaní závažnosti užívania alkoholu vzhl'adom na stav sme zistili, že slobodní pacienti vykazujú závažnejšiu mieru užívania alkoholu ako pacienti v manželskom zväzku $(U=1423,50$; sig.=0,01), kde tento rozdiel reprezentuje malý efekt $(r=0,24)$. Slobodní pacienti vykazujú závažnejšiu mieru užívania alkoholu aj ako rozvedení pacienti $(\mathrm{U}=1304,00$; sig. $=0,02)$, kde tento rozdiel reprezentuje taktiež malý efekt $(\mathrm{r}=0,21)$. V miere psychopatológie $(\mathrm{K}-\mathrm{W}=0,10$; sig. $=0,95)$ sa v súvislosti s rodinným stavom signifikantné rozdiely nevyskytli.

Najčastejšie bývali pacienti so svojim partnerom (38,1\%), takmer tretina z nich žila s rodičmi (30,4\%), 18,6 \% pacientov žilo osamote a 9,7\% pacientov žilo s inými príbuznými alebo priatel'mi. Len $25 \%$ pacientov malo deti. Vzhl'adom na tieto charakteristiky neboli medzi pacientmi signifikantné rozdiely v závažnosti užívania alkoholu $(K-W=1,97 ;$ sig. $=0,58)$ ani v miere psychopatológie (K-W=3,00; sig.=0,39).

\section{Komorbidity u závislosti od alkoholu}

Podobne ako v zahraničných epidemiologických štúdiách (e. g. Grant et al., 2004), takmer $60 \%$ pacientov malo okrem závislosti od alkoholu aj minimálne jednu d'alšiu pridruženú psychiatrickú diagnózu. Okrem diagnóz súvisiacich s užívaním alkoholu $(8,5 \%)$ a iných psychoaktívnych látok ako tabak (40\%), sedatív a hypnotík (2,5\%), kanabis (1\%), prípadne viacerých drog a iných psychoaktívnych látok (3,5\%), šlo najčastejšie o afektívne poruchy $(5,5 \%)$, neurotické, stresom podmienené a somatoformné poruchy (5\%), poruchy osobnosti (4\%), organické duševné poruchy (4\%), patologické hráčstvo $(3,5 \%)$, či schizofrénie, schizotypové poruchy a poruchy s bludmi (2 \%). Väčšina pacientov (66,3 \%) mala predpisované aj psychofarmaká. 


\section{Dotazník AUDIT}

Dotazník AUDIT vyplnilo na začiatku liečby 212 pacientov s priemerným skóre 25,02 $(\mathrm{SD}=6,98)$, čo zodpovedá škodlivému pitiu na úrovni zvislosti od alkoholu. 1,4 \% zo súboru (n=3) zaznamenali skóre, ktoré nie je indikátorom škodlivého pitia, 6,1 \% (n=13) skórovalo do pásma strednej úrovne problémov s alkoholom. 14,7 \% $(\mathrm{n}=31)$ pacientov skórovalo do pásma vysokej úrovne problémov s alkoholom, kým zvyšných 75,9 \% (n=166) skórovalo do pásma závislosti od alkoholu.

Graf č.1: Podiel pacientov v jednotlivých dimenziách škodlivého pitia p. dotazníka AUDIT

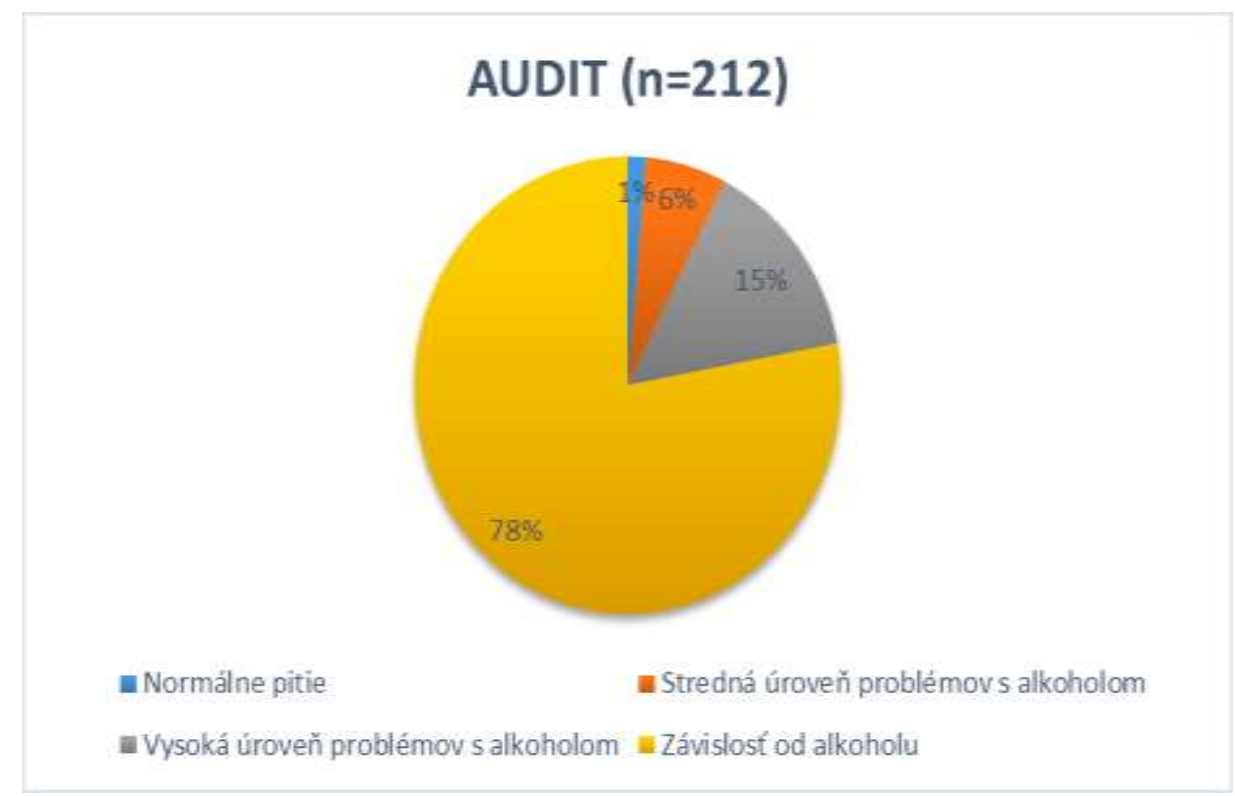

\section{Vzt’ah závažnosti užívania alkoholu a psychopatológie}

Na overenie vzt'ahu medzi závažnost’ou užívania alkoholu a úrovňou psychopatológie sme medzi výsledným skóre dotazníka AUDIT a skóre v jednotlivých subškálach dotazníka SCL-90 aplikovali štatistické testovanie korelácií (Pearson). Výsledky preukázali prítomnost' signifikantných korelácií medzi všetkými sledovanými premennými a uvádzame ich v tabul'ke č. 1.

Tabul'ka č. 1: Korelačné vzt'ahy medzi skóre dotazníka audit a škálami SCL - 90

\begin{tabular}{lll} 
Škály SCL-90 & r & sig. \\
\hline Somatizácia & 0,36 & 0,00 \\
Obsesie a kompulzie & 0,40 & 0,00 \\
Interpersonálna senzitivita & 0,36 & 0,00 \\
Depresia & 0,36 & 0,00 \\
Anxieta & 0,39 & 0,00 \\
Hostilita & 0,29 & 0,00 \\
Fóbia & 0,30 & 0,00
\end{tabular}


Paranoidná ideácia

$0,33 \quad 0,00$

Psychoticizmus

$0,32 \quad 0,00$

Celkové patologické skóre (Global severity index)

$0,40 \quad 0,00$

$\mathrm{r}$ - hodnota korelačného koeficientu (Pearson), sig. - signifikancia

\section{Zmena psychopatológie počas liečby}

$\mathrm{Na}$ mieru psychopatológie bolo vo výskumnom súbore s časovým odstupom opakovane dotazovaných 146 pacientov. Tí, ktorí vyplnili dotazníky SCL-90 na začiatku liečby a po 6 týždňoch (n=61), vykazovali signifikantnú redukciu psychopatologických symptómov vyjadrenej GSI indexom po 6 týždňoch $v$ porovnaní so začiatkom liečby $(Z=6,19$; sig. $=0,00)$, pričom tento rozdiel reprezentuje vel'ký efekt $(\mathrm{r}=0,79)$. Pacienti, ktorí boli dotazovaní na začiatku liečby a na konci liečby skôr ako v 12. týždni $(\mathrm{n}=29)$, taktiež vykazovali signifikantnú redukciu psychopatologických symptómov na konci liečby $\mathrm{v}$ porovnaní so začiatkom liečby $(\mathrm{Z}=4,23$; sig. $=0,00)$, pričom aj tento rozdiel reprezentuje vel'ký efekt $(r=0,78)$. Pacienti, ktorí boli dotazovaní na začiatku liečby a na konci liečby po 12. týždňoch $(n=15)$, taktiež vykazovali signifikantnú redukciu psychopatologických symptómov na konci liečby $\mathrm{v}$ porovnaní so začiatkom liečby $(Z=3,18$; sig. $=0,00)$ a aj tento rozdiel predstavuje vel'ký efekt $(r=0,82)$. A napokon pacienti, ktorí boli dotazovaní v 6. týždni a na konci liečby v 12. týždni $(n=41)$, síce vykazovali pokles miery psychopatológie na konci liečby v porovnaní so 6. týždňom liečby, uvedený pokles však iba tesne nesplnil kritéria štatistickej významnosti $(Z=1,50$; sig.=0,13). Profil skóre subškál SCL-90 v rôznych fázach liečby vzhl’adom ku cut-off skóre znázorňujeme na grafe č. 2. 0 zmenách v jednotlivých subškálach SCL-90 referujeme v osobitných odsekoch.

Graf č. 2: Profil skóre subškál SCL-90 v rôznych fázach liečby vzhl'adom ku cut-off skóre

\section{Skóre subškál SCL-90 v rôznych fázach liečby}

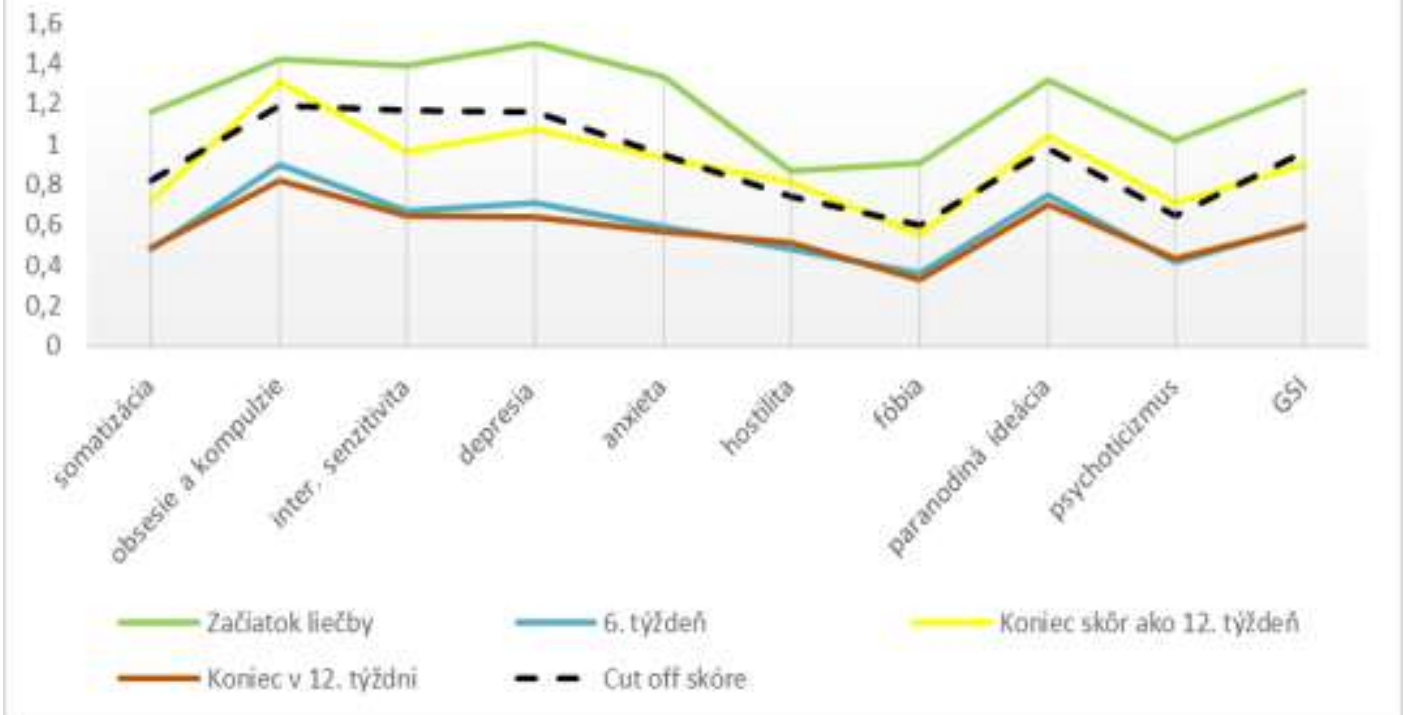




\section{Zmena v subškále somatizácie počas liečby}

Medzi začiatkom liečby a 6. týždňom dvanást'týždňovej liečby došlo u pacientov k vel'kému a signifikantnému zníženiu skóre v subškále somatizácie ( $\mathrm{n}=61, \mathrm{r}=0,61, \mathrm{Z}=4,74$; sig=0,00). Okrem toho sme $\mathrm{v}$ tejto subškále zaznamenali signifikantný a vel'ký pokles symptómov u pacientov medzi začiatkom liečby a koncom skôr ako v 12 . týždni $(n=30, r=0,69, Z=3,71$; sig.=0,00) a u pacientov medzi začiatkom liečby a koncom liečby v 12. týždni ( $n=15, Z=2,34$; sig.=0,02), kde táto zmena taktiež reprezentovala vel'ký efekt $(\mathrm{r}=0,60)$. Pri porovnaní skóre v subškále somatizácie pacientov v 6. týždni a na konci liečby v 12 týždni sme signifikantné zmeny nezaznamenali $(\mathrm{n}=41$, $\mathrm{Z}=0,2$; sig. $=0,36$ ).

\section{Zmena v subškále obsesií a kompulzií počas liečby}

Medzi začiatkom liečby a 6 . týždňom dvanást'týždňovej liečby došlo $\mathrm{u}$ pacientov $\mathrm{k}$ signifikantnému a vel'kému zníženiu skóre v subškále obsesií a kompulzií ( $n=61, r=0,67, Z=5,25$; sig.=0,00). Okrem toho sme v tejto subškále zaznamenali signifikantný a vel'ký pokles symptómov u pacientov medzi začiatkom liečby a koncom liečby skôr ako v 12. týždni $(n=29, r=0,50, Z=2,68$; sig.=0,01). Pokles v subškále obsesí a kompulzií u pacientov medzi začiatkom liečby a koncom liečby v 12. týždni $(n=15, Z=3,05$; sig. $=0,00)$ bol taktiež signifikantný a reprezentoval vel'ký efekt $(\mathrm{r}=0,79)$. Pri porovnaní skóre $\mathrm{v}$ subškále obsesií a kompulzií pacientov v 6 . týždni a na konci liečby v 12 týždni, sme taktiež zaznamenali signifikantný pokles stredne vel'kého efektu $(n=41$, $r=0,34, Z=2,19$; sig.=0,03).

\section{Zmena v subškále interpersonálnej senzitivity počas liečby}

Medzi začiatkom liečby a 6 . týždňom dvanást'týždňovej liečby došlo u pacientov k signifikantnému a vel'kému zníženiu skóre v subškále interpersonálnej senzitivity ( $\mathrm{n}=61$, $\mathrm{r}=0,78, \mathrm{Z}=6,07$; sig.=0,00). Okrem toho sme u pacientov $\mathrm{v}$ tejto subškále zaznamenali signifikantný a vel'ký pokles symptómov medzi začiatkom liečby a koncom liečby skôr ako v 12 . týždni $(n=29, r=0,82, Z=4,40$; sig. $=0,00)$ a u pacientov medzi začiatkom liečby a koncom liečby v 12. týždni $(n=15, Z=2,99 ;$ sig. $=0,00)$ tento pokles reprezentuje vel'ký efekt $(r=0,77)$. Pri porovnaní skóre v subškále interpersonálnej senzitivity pacientov v 6. týždni a na konci liečby v 12 . týždni sme signifikantné zmeny nezaznamenali, aj ked' tendencia k poklesu bola zjavná $(n=41, Z=1,59$; sig.=0,07).

\section{Zmena v subškále depresie počas liečby}

Medzi začiatkom liečby a 6. týždňom dvanást'týždňovej liečby došlo u pacientov k signifikantnému zníženiu skóre v subškále depresie ( $n=61, \mathrm{Z}=6,07$; sig.=0,00), kde tento pokles reprezentuje vel'ký efekt $(\mathrm{r}=0,78)$. Okrem toho sme $\mathrm{v}$ tejto subškále zaznamenali signifikantný a významný pokles symptómov u pacientov medzi začiatkom liečby a koncom liečby skôr ako v 12 . týždni $(\mathrm{n}=29, \mathrm{r}=0,65, \mathrm{Z}=3,49$; sig. $=0,00)$ a u pacientov medzi začiatkom liečby a koncom liečby $\mathrm{v}$ 12. týždni $(n=15, Z=3,30 ;$ sig. $=0,00)$ tento rozdiel reprezentuje vel'ký efekt $(r=0,85)$. Pri porovnaní skóre v subškále depresie u pacientov v 6. týždni a na konci liečby v 12. týždni sme signifikantné zmeny nezaznamenali ( $\mathrm{n}=41, \mathrm{Z}=1,14$; sig.=0,17). 


\section{Zmena v subškále anxiety počas liečby}

Medzi začiatkom liečby a 6. týždňom dvanást'týždňovej liečby došlo u pacientov k signifikantnému zníženiu skóre $\mathrm{v}$ subškále anxiety $(\mathrm{n}=61, \mathrm{Z}=5,69$; sig. $=0,00)$, pričom tento rozdiel reprezentuje vel'ký efekt $(\mathrm{r}=0,73)$. Okrem toho sme $\mathrm{v}$ tejto subškále zaznamenali signifikantný a vel'ký pokles symptómov u pacientov medzi začiatkom liečby a koncom liečby skôr ako v 12. týždni $(n=29, r=0,67, Z=3,59$; sig.=0,00). U pacientov medzi začiatkom a koncom liečby v 12. týždni $(n=15, Z=3,41$; sig. $=0,00)$ tento pokles taktiež reprezentuje vel'ký efekt $(\mathrm{r}=0,88)$. Pri porovnaní skóre v subškále anxiety pacientov v 6. týždni a na konci liečby v 12 . týždni sme rovnako zaznamenali signifikantný pokles stredne vel'kého efektu $(n=41, r=0,38$, $\mathrm{Z}=2,43$; sig.=0,03).

\section{Zmena v subškále hostility počas liečby}

Medzi začiatkom liečby a 6. týždňom dvanásttýždňovej liečby došlo u pacientov k signifikantnému zníženiu skóre $v$ subškále hostility $(n=61, Z=2,91$; sig.=0,00), pričom tento pokles reprezentuje stredne vel'ký efekt $(\mathrm{r}=0,37)$. Okrem toho sme $\mathrm{v}$ tejto subškále zaznamenali signifikantný a to stredne vel'ký pokles symptómov u pacientov medzi začiatkom liečby a koncom liečby skôr ako v 12. týždni ( $n=29, r=0,46, Z=2,50$; sig.=0,01). Medzi začiatkom liečby a koncom liečby v 12. týždni $(n=15, Z=0,63$; sig. $=0,53)$ a ani pri porovnaní skóre v subškále hostility pacientov v 6. týždni a na konci liečby v 12. týždni sme signifikantné zmeny nezaznamenali $(n=41, Z=1,18$; sig.=0,24).

\section{Zmena v subškále fóbie počas liečby}

Medzi začiatkom liečby a 6 . týždňom dvanást'týždňovej liečby došlo u pacientov k signifikantnému zníženiu skóre v subškále fóbie ( $n=61, Z=4,26$; sig.=0,00), pričom tento pokles reprezentuje vel'ký efekt $(\mathrm{r}=0,55)$. Okrem toho sme $\mathrm{v}$ tejto subškále zaznamenali signifikantný a vel'ký pokles symptómov u pacientov medzi začiatkom liečby a koncom liečby skôr ako v 12 . týždni (n=29, r=0,74, Z=3,97; sig.=0,00), tiež u pacientov medzi začiatkom liečby a koncom liečby v 12. týždni $(n=15, Z=2,11$; sig. $=0,04)$ tento pokles tiež reprezentuje vel'ký efekt $(r=0,55)$. Pri porovnaní skóre v subškále fóbie pacientov v 6 . týždni a na konci liečby v 12 . týždni sme síce zaznamenali pokles symptómov, ktorý iba tesne nedosahuje hranicu štatistickej významnosti $(n=41, Z=1,85 ;$ sig.=0,07).

\section{Zmena v subškále paranoidnej ideácie počas liečby}

Medzi začiatkom liečby a 6. týždňom dvanást'týždňovej liečby došlo u pacientov k signifikantnému zníženiu skóre v subškále paranoidnej ideácie (n=61, Z=5,05; sig.=0,00), pričom tento pokles reprezentuje vel'ký efekt $(\mathrm{r}=0,65)$. Taktiež sme v tejto subškále zaznamenali signifikantný a vel'ký pokles symptómov u pacientov medzi začiatkom liečby a koncom liečby skôr ako v 12. týždni ( $n=29, r=0,62, Z=3,33$; sig. $=0,00)$ a u pacientov medzi začiatkom liečby a koncom liečby v 12. týždni ( $n=15, \mathrm{Z}=2,20$; sig.=0,03) tento pokles reprezentuje taktiež vel'ký efekt $(\mathrm{r}=0,57)$. Pri porovnaní skóre v subškále paranoidnej ideácie pacientov v 6 . týždni a na konci liečby v 12. týždni sme signifikantné zmeny nezaznamenali $(n=41, Z=1,76$; sig.=0,08), pozorovaný pokles v tejto subškále tesne atakoval hranicu štatistickej významnosti. 


\section{Zmena v subškále psychoticizmu počas liečby}

Medzi začiatkom liečby a 6. týždňom dvanást'týždňovej liečby došlo u pacientov k signifikantnému zníženiu skóre v subškále psychoticizmu $(n=61, Z=5,20$; sig.=0,00), kde tento pokles reprezentuje vel'ký efekt $(\mathrm{r}=0,67)$. Okrem toho sme $\mathrm{v}$ tejto subškále zaznamenali signifikantný a vel'ký pokles symptómov u pacientov medzi začiatkom liečby a koncom liečby skôr ako v 12. týždni ( $n=29, r=0,81, Z=4,39$; sig. $=0,00)$ a u pacientov medzi začiatkom liečby a koncom liečby v 12 . týždni $(n=15, Z=2,51$; sig.=0,01), tento pokles tiež svedčí tiež pre vel'ký efekt $(\mathrm{r}=0,65)$. Pri porovnaní skóre v subškále psychoticizmu pacientov v 6 . týždni a na konci liečby v 12. týždni sme signifikantné zmeny nezaznamenali ( $n=41, \mathrm{Z}=0,94 ;$ sig.=0,35).

\section{DISKUSIA}

Výsledky ukázali signifikantný vzt’ah medzi závažnost'ou užívania alkoholu a mierou psychopatológie, čo potvrdzuje prvú hypotézu. K vel'mi podobným výsledkom vo svojom výskume dospeli napr. aj Schaefer, Sobieraj a Hollyfield (1987), prípadne Landa et al. (1995), ktorí taktiež zistili signifikantný vzt'ah medzi závažnost'ou užívania alkoholu a množstvom a intenzitou psychopatologických symptómov u hospitalizovaných, resp. ambulantných od alkoholu závislých pacientov. Ked'že sa zistil štatisticky významný vzt’ah medzi závažnost'ou pacientovej závislosti (hodnotený dot. AUDIT) a mierou psychopatológie (tab. č.1), je pravdepodobné, že prerušenie užívania alkoholu by výrazne zredukovalo závažnost' psychopatológie meranej dotazníkom SCL-90. V súvislosti s našou výskumnou otázkou, miera poklesu psychopatológie nie je u všetkých škál rovnaká, škály, ktoré viac súvisia s osobnostnou štruktúrou (napr. hostilita, v prvých 6 týždňoch efekt 0,37 oproti depresii 0,78 ), sú odolnejšie ako voči farmakologickému, tak voči terapeutickému prístupu a menej ich ovplyvní v priebehu liečby aj abstinencia. Somatizačné a úzkostno-depresívne stavy reagujú na liečbu vel'mi dobre a stabilizujú sa už po prvých šiestich týždňoch. V škále obsesií, kompulzií a úzkosti sa prejavuje signifikantný pokles aj v čase liečby od 6 - 12 týždňov. Práve práca s prechodom z chráneného do prirodzeného prostredia teda úzko súvisí s reštrukturáciou množstva obavných, či ruminačných myšlienok a s úpravou psychického stavu s dominujúcou obsesívno - kompulzívnou zložkou (myšlienky spojené s cravingom).

Výskumná otázka bola zameraná na psychopatologické fenomény u pacientov a ich zmenu v priebehu liečenia. Mieru psychopatologických symptómov sme merali dotazníkom SCL-90. Miera závažnosti celkového skóre vyjadreného GSI indexom indikuje, že porovnávaním začiatku liečby, kde prevažovala klinicky závažná úroveň psychopatológie, $\mathrm{v}$ d’alších fázach liečby dochádza $\mathrm{k}$ signifikatnému poklesu jej závažnosti a nárastu počtu pacientov $\mathrm{s}$ normálnu úrovňou psychopatológie. Pacienti, ktorý ukončili liečbu v 12 týždni, vykazovali na konci liečby signifikantne nižšiu mieru psychopatológie, než pacienti končiaci liečbu v 6 týždni a to vo všetkých subškálach SCL, s výnimkou subškály fóbie. Možno ale predpokladat', že k najvýraznejšiemu poklesu psychopatológie dochádza v prvých týždňoch liečby. Pacient príde obvykle v závažnom stave, následne je medikovaný, klinický stav sa stabilizuje, dochádza $\mathrm{k}$ úprave somatického stavu, začína chodit' na terapeutické skupiny, v dôsledku čoho dôjde $\mathrm{k}$ výraznejšiemu ústupu psychopatológie. Nástup efektu psychoterapie v porovnaní s medikáciou je síce pomalší, ale zase s dlhodobejším efektom. Práve pokles psychopatológie je nutný, aby bolo možné terapeuticky s pacientom pracovat', pretože prestáva byt' blokovaná jeho kognitívna kapacita a tým pádom dokáže efektívnejšie pracovat' v rámci skupinovej terapie. Je otázne, či by sa pri prípadnom predížení liečby dosiahol iný, štatisticky významnejší rozdiel (medzi 6 a 12 týždňom, resp. koncom liečby). Porovnanie miery psychopatológie $s$ komorbídnymi diagnostickými kategóriami, s ktorými pacienti prišli na liečenie (afektívne poruchy 5,5 \%, 
neurotické, stresom podmienené a somatoformné poruchy $5 \%$, poruchy osobnosti $4 \%$, organické duševné poruchy $4 \%$, patologické hráčstvo 3,5 \% či schizofrénia, schizotypové poruchy a poruchy s bludmi $2 \%$ ), naznačuje, že bud' sa tieto poruchy nediagnostikujú dostatočne, alebo výrazná psychopatológia meraná dotazníkom je typická pre závislosti a pri liečbe primárnej diagnózy dochádza $\mathrm{k}$ jej čiastočnému ústupu. Výsledky výskumu poukazujú na to, že aj 6 týždňová liečba je na dosiahnutie výrazného poklesu psychopatológie dostatočne účinná. Výhodou 12 týždennej liečby je však d'alšie zníženie psychopatológie.

\section{LITERATÚRA}

Babor, T. F., La Fuente, J. R., Saunders, J., \& Grant, M. (1992). AUDIT: the Alcohol Use Disorders Identifcation Test: guidelines for use in primary health care. Geneva: Substance Abuse Department, World Health Organization, WHO/PSA.

Derogatis L. R. (1992). SCL-90-R: Administration, Scoring of Procedures Manual-II for the R (evised) Version and Other Instruments of the Psychopathology Rating Scale Series. Clinical Psychometric Research Incorporated.

Dongier, M. (2005). What are the treatment options for comorbid alcohol abuse and depressive disorders? Journal of Psychiatry and Neuroscience, 30(3), 224.

Ewusi-Mensah, I., Saunders, J. B., Johnson, R. D., \& Wiliams, R. (1986). Alcohol dependence and psychopathology in alcoholic liver disease. British journal of addiction, 81(2), 231-235.

Grant, B .F., Stinson, F. S., Dawson, D. A., Chou, S. P., Ruan, W. J., \& Pickering, R. P. (2004). Cooccurrence of 12-month alcohol and drug use disorders and personality disorders in the United States: results from the National Epidemiologic Survey on Alcohol and Related Conditions. Alcoholism Clinical and Experimental Research, 61(4), 361-368.

Ipser, J. C., Wilson, D., Akindipe, T. O., Sager, C., \& Stein, D. J. (2015). Pharmacotherapy for anxiety and comorbid alcohol use disorders. The Cochrane Library of Systematic Reviews.

Landa, N., Fernandez-Montalvo, J., Lopez-Goni, J. J., \& Lorea, I. (1995). Psychopathological comorbidity in alcoholism: A descriptive study. International Journal of Clinical and Health Psychology.

Regier, D. A., Farmer, M. E., Rae, D. S., Locke, B. Z., Keith, S. J., Judd, L. L., \& Goodwin, F.K. (1990). Comorbidity of mental disorders with alcohol and other drug abuse. Results from the Epidemiologic Catchment Area (ECA) Study. JAMA, 264(19), 2511-2518.

Schaeffer, M. R., Sobieraj, K., \& Hollyfield, R. L. (1987). Severity of alcohol dependence and its relationship to additional psychiatric symptoms in male alcoholic inpatients. The American Journal of Drug and Alcohol Abuse, 13(4), 435-447.

World Health Organisation (1993). International Statistical Classification of Disease and Related Health Problems (1st ed.). Geneva: World Health Organization. 


\title{
Changes in Psychopathology in Alcohol-Dependent Patients Related to Length of Treatment and Relationships to Alcohol Consumption
}

\begin{abstract}
The study objective was to analyse the relationships between the severity of the pattern of alcohol consumption and psychopathology levels in alcohol-dependent patients, and compare the changes in psychopathology during treatment related to length of treatment in three different addiction treatment facilities in the Slovak Republic, the Czech Republic and Poland. The sample consisted of 380 alcohol-dependent patients (282 men and 98 women) with an average age 44.58 years $(+10.48)$. Out of the total, 212 patients were treated in the rehabilitation centre OLÚP Predná Hora, 117 in the facility Wotuw Krakow, and 51 patients were from the psychiatric hospital Jemnice. Sixty per cent of the patients had at least one other psychiatric diagnosis. The screening tool AUDIT (Alcohol Use Disorder Identification Test) and the questionnaire of psychopathology SCL-90 (Symptom Checklist 90), including nine dimensions, were administered to the study respondents. We proved a significant relationship between all scales of the SCL-90 and the final scores of the AUDIT. We found significant differences between the final scores of the SCL-90 at the beginning and the end of the treatment; the most significant decrease of psychopathology occurs in the first six weeks of treatment.
\end{abstract}

Keywords: Alcohol consumption, Treatment, Psychopatology 